\title{
Influence of lime and secondary nutrients on available nutrients and yield of paddy
}

\author{
S. M. Jayaprakash ${ }^{1^{*}}$, S. U. Patil ${ }^{2}$, T. H. Ranjith ${ }^{1}$, R. Jayaprakash ${ }^{3}$ \\ and K. V. Sudhir Kamath ${ }^{4}$ \\ ${ }^{1}$ Department of Soil Science \& Agricultural Chemistry, ZAHRS, Brahmavar, India \\ ${ }^{2}$ ZAHRS, Brahmavar, India \\ ${ }^{3}$ Krishi Vigyan Kendra, Brahmavar, Udupi, India \\ ${ }^{4}$ Department of Agronomy ZAHRS, Brahmavar, India \\ *Corresponding author
}

\section{Keywords \\ Paddy, nutrient, acidity, lime, levels, yield}

Article Info

Accepted:

15 January 2020

Available Online:

10 February 2020

\section{A B S T R A C T}

A field experiment was conducted during kharif season of 2014, 2015 and 2016 at Zonal Agricultural and Horticultural Research Station, Brahmavar, Udupi district, Karnataka, to study the effect of soil acidity and secondary nutrient management on soil available nutrients and yield of paddy. The experiment was laid out in RCBD design with three replications and nine treatments involving different levels of lime applications and magnesium sulphate in comparison to package of practice as control. Significantly higher exchangeable magnesium, Grain and straw yield was found in treatment T5: which received POP+Lime application equivalent to 50\% exchangeable acidity and $40 \mathrm{~kg}$ Magnesium sulphate and treatment T9: which received POP+Lime application equivalent to $100 \%$ exchangeable acidity and $40 \mathrm{~kg}$ Magnesium sulphate followed by treatment T8: which received POP+Lime application equivalent to $100 \%$ exchangeable acidity and $30 \mathrm{~kg}$ Magnesium sulphate.

\section{Introduction}

In India rice crop plays vital role in our national food security and is a means of livelihood for millions of rural households. India is the world's second largest producer (129.2 million tonne) of rice on an area of 43 million ha and with the productivity of 3 tonnes per ha (Anon. 2012- 13) and ranks next to china. the current and future food security of the country is only feasible by harnessing the huge untapped potential of rainfed agriculture through improved management of land, water, nutrients, and other natural resources (Rockstrom et al., 2007; Wani, et al., 2012b; Wani, et al., 
2009). At the accelerating current growth rate of 1.8 per cent of population in India rice requirement by $2020 \mathrm{AD}$ is projected around 140 million tonnes. The rapid increasing in food production over the past three decades was at the cost of corresponding increase in the removal of nutrient from the soil.

Soil fertility is a dynamic natural property and it can change under the influence of natural and human induced factors. Soil organic matter is an important factor in deciding management system of the forest soil fertility. The forest soils vary in physico-chemical changes with time and space resulting in variation among topography, climate, weathering processes, vegetation cover and microbial activities and also biotic and abiotic factors (Sannappa and Manjunath., 2013).

Soil fertility fluctuates throughout the growing season each year due to alteration in the quantity and availability of mineral nutrients by the addition of fertilizers, manure, compost, mulch and lime in addition to leaching. The negligence shown to the conservation and use of organic sources of nutrients has not only caused the exhaustion of soil nutrient reserves but also resulted in an imbalance among the available nutrients leading to soil problems. In acidic soils less availability of nutrients ( $\mathrm{N}, \mathrm{P}, \mathrm{K}, \mathrm{Ca}, \mathrm{Mg}$ and $\mathrm{S})$ besides inadequate nutrient management practices.

Paddy is an exhaustive crop and removes large amount of macro and micro nutrients from soil (Singh and Singh, 2001). Though many nutrient management studies have been carried out in paddy, the location specific study on soil acidity and secondary nutrient management in rice for the farmers of coastal region of Karnataka is not up to the mark. Keeping the above points in view, a field investigation has been carried out to study the effect of soil acidity and secondary nutrient management on soil available nutrients and yield of paddy.

\section{Materials and Methods}

A field experiment was conducted during kharif season of 2014, 2015 and 2016 at Zonal Agricultural and Horticultural Research Station, Brahmavar, Udupi district, Karnataka, to study the effect of soil acidity and secondary nutrient management on soil available nutrients and yield of paddy. The experimental site is situated between $74^{0} 45^{\prime}$ to $74^{0} 46^{\prime}$ East longitude and $13^{\circ} 24^{\prime} 45^{\prime \prime}$ to $13^{0} 25^{\prime}$ North latitude and an altitude of 25 meters above mean sea level. Soil type is sandy loam in texture and $\mathrm{pH}$ was acidic (5.24).

The soil was medium in available nitrogen (348.70 kg ha-1), high in available phosphorus (89.21 kg ha-1 ) and medium in available potassium (62.08 $\mathrm{kg}$ ha-1 ). The organic carbon content was high $(0.968 \%)$ in range. MO-4 (Red rice) a popular medium duration variety was transplanted in July with a spacing of $20 \mathrm{~cm} \mathrm{X} 10 \mathrm{~cm}$. Experiment included nine treatments treatments consisted of $\mathrm{T}_{1}: 100 \%$ NPK (POP; $\mathrm{N}: \mathrm{P}: \mathrm{K}=60: 30: 60$ $\mathrm{kgs} / \mathrm{ha}), \mathrm{T}_{2}: \mathrm{T}_{1}+$ Lime application equivalent to $50 \%$ exch.

Acidity, $\mathrm{T}_{3}: \mathrm{T}_{2}+20 \mathrm{~kg}$ magnesium sulphate, $\mathrm{T}_{4}: \mathrm{T}_{2}+30 \mathrm{~kg}$ magnesium sulphate, $\mathrm{T}_{5}: \mathrm{T}_{2}+$ $40 \mathrm{~kg}$ magnesium sulphate, $\mathrm{T}_{6}: \mathrm{T}_{1}+$ Lime application equivalent to $100 \%$ exch. Acidity, $\mathrm{T}_{7}: \mathrm{T}_{6}+20 \mathrm{~kg}$ magnesium sulphate, $\mathrm{T}_{8}: \mathrm{T}_{6}+$ $30 \mathrm{~kg}$ magnesium sulphate, $\mathrm{T}_{9}: \mathrm{T}_{6}+40 \mathrm{~kg}$ magnesium sulphate.

Yield (biological and economical) was recorded from individual plots at harvest and converted to $\mathrm{kg} / \mathrm{ha}$. Composite soil sample were used to assess soil nutrient status. Standard statistical methods were used for comparing the treatment means. 


\section{Results and Discussion}

The results obtained from three years of experiment is pooled and analyzed using standard statistical tools. Results pertaining to the effect of soil acidity and secondary nutrient management on soil available nutrients are presented in Table 1. Results shown that there is no significant difference was observed among the treatments in case of in $\mathrm{pH}$, electrical conductivity, organic carbon, soil available Phosphorus, potassium, exchangeable calcium and exchangeable acidity.

Table.1 Experimental site soil properties and the grain \& straw yield of paddy

\begin{tabular}{|c|c|c|c|c|c|c|c|c|c|}
\hline \multirow{2}{*}{\multicolumn{2}{|c|}{ Treatments Details }} & \multirow{3}{*}{$\begin{array}{c}\mathbf{p H} \\
5.24\end{array}$} & \multirow{3}{*}{$\begin{array}{c}\text { EC } \\
\mathrm{dSm}^{-1} \\
0.043\end{array}$} & \multirow{3}{*}{$\begin{array}{c}\text { OC } \\
\% \\
0.968\end{array}$} & \multirow{3}{*}{$\begin{array}{c}\text { Av. } \\
\mathbf{P}\end{array}$} & \multirow{3}{*}{$\begin{array}{c}\text { Av. } \\
\mathbf{K} \\
\mathrm{Kg} / \mathrm{ha} \\
62.08\end{array}$} & \multirow{2}{*}{\multicolumn{2}{|c|}{\begin{tabular}{l|c|}
$\begin{array}{l}\text { Ex. } \\
\text { Ca }\end{array}$ & Ex. \\
\multicolumn{2}{|c|}{ C.mol $\left(\mathrm{P}^{+}\right) \mathrm{kg}$} \\
\end{tabular}}} & \multirow{2}{*}{$\begin{array}{r}\text { Ex. } \\
\text { Ac. } \\
\text { soil }\end{array}$} \\
\hline & & & & & & & & & \\
\hline & Initial & & & & & & 0.479 & 0.388 & 0.537 \\
\hline $\mathbf{T}_{1}$ & $\begin{array}{l}\text { 100\% NPK (POP; } \\
\text { N:P:K= 60:30:60 kgs/ha) }\end{array}$ & 5.26 & 0.058 & 0.949 & 80.81 & 63.78 & 0.586 & 0.395 & 0.523 \\
\hline $\mathbf{T}_{2}$ & $\begin{array}{l}\mathrm{T}_{1}+\text { Lime application } \\
\text { equivalent to } 50 \% \text { exch. } \\
\text { acidity }\end{array}$ & 5.27 & 0.041 & 0.904 & 79.43 & 65.29 & 0.464 & 0.397 & 0.520 \\
\hline $\mathbf{T}_{3}$ & $\begin{array}{l}\mathrm{T}_{2}+20 \mathrm{~kg} \text { magnesium } \\
\text { sulphate }\end{array}$ & 5.22 & 0.037 & 0.963 & 82.83 & 59.22 & 0.450 & 0.461 & 0.517 \\
\hline $\mathbf{T}_{4}$ & $\begin{array}{l}\mathrm{T}_{2}+30 \mathrm{~kg} \text { magnesium } \\
\text { sulphate }\end{array}$ & 5.11 & 0.084 & 1.000 & 83.08 & 61.48 & 0.398 & 0.490 & 0.488 \\
\hline $\mathbf{T}_{5}$ & $\begin{array}{l}\mathrm{T}_{2}+40 \mathrm{~kg} \text { magnesium } \\
\text { sulphate }\end{array}$ & 5.05 & 0.037 & 0.970 & 83.84 & 58.78 & 0.481 & $0.525^{\mathrm{a}}$ & 0.530 \\
\hline $\mathbf{T}_{6}$ & $\begin{array}{l}\mathrm{T}_{1}+\text { Lime application } \\
\text { equivalent to } 100 \% \text { exch. } \\
\text { acidity }\end{array}$ & 5.21 & 0.044 & 0.973 & 87.12 & 60.92 & 0.517 & 0.419 & 0.574 \\
\hline $\mathbf{T}_{7}$ & $\begin{array}{l}\mathrm{T}_{6}+20 \mathrm{~kg} \text { magnesium } \\
\text { sulphate }\end{array}$ & 5.20 & 0.038 & 0.963 & 86.52 & 62.03 & 0.597 & 0.494 & 0.500 \\
\hline $\mathbf{T}_{8}$ & $\begin{array}{l}\mathrm{T}_{6}+30 \mathrm{~kg} \text { magnesium } \\
\text { sulphate }\end{array}$ & 5.15 & 0.052 & 1.015 & 86.17 & 63.81 & 0.585 & 0.500 & 0.446 \\
\hline $\mathbf{T}_{9}$ & $\begin{array}{l}\mathrm{T}_{6}+40 \mathrm{~kg} \text { magnesium } \\
\text { sulphate }\end{array}$ & 5.06 & 0.044 & 0.973 & 85.93 & 64.77 & 0.501 & $0.511^{\mathrm{a}}$ & 0.543 \\
\hline & SEM \pm & ---- & --- & --- & ---- & --- & ---- & 0.027 & ---- \\
\hline & $\mathrm{CV}$ & & & & & & & 12.095 & \\
\hline & $\mathrm{CD}(5 \%)$ & NS & NS & NS & NS & NS & NS & 0.081 & NS \\
\hline
\end{tabular}


Table.2 Effect of Lime application and secondary nutrient management on Grain and straw yield of paddy over the years $\left(\mathrm{Kg} \mathrm{ha}^{-1}\right)$

\begin{tabular}{|c|c|c|c|c|c|c|c|}
\hline \multicolumn{2}{|r|}{ Treatments } & \multicolumn{2}{|c|}{2014} & \multicolumn{2}{|c|}{2015} & \multicolumn{2}{|c|}{2016} \\
\hline & & $\begin{array}{l}\text { Grain } \\
\text { yield }\end{array}$ & $\begin{array}{l}\text { Straw } \\
\text { yield }\end{array}$ & $\begin{array}{l}\text { Grain } \\
\text { yield }\end{array}$ & $\begin{array}{l}\text { Straw } \\
\text { yield }\end{array}$ & $\begin{array}{l}\text { Grain } \\
\text { yield }\end{array}$ & $\begin{array}{c}\text { Straw } \\
\text { yield }\end{array}$ \\
\hline $\mathbf{T}_{1}$ & $\begin{array}{c}\text { 100\% NPK } \\
\text { (POP;N:P:K= } \\
\text { 60:30:60 kgs/ha) }\end{array}$ & 5743 & 6318 & 5685 & 6338 & 5648 & 6683 \\
\hline $\mathbf{T}_{2}$ & $\mathrm{~T}_{1}+$ Lime $50 \% \mathrm{EA}$ & 6343 & 7612 & 6362 & 7203 & 6285 & 7055 \\
\hline $\mathbf{T}_{3}$ & $\mathrm{~T}_{2}+20 \mathrm{~kg} \mathrm{MgSO}_{4}$ & 6580 & 7567 & 6432 & 7053 & 6598 & 7773 \\
\hline $\mathbf{T}_{4}$ & $\mathrm{~T}_{2}+30 \mathrm{~kg} \mathrm{MgSO}_{4}$ & 7677 & 8598 & 7365 & 7680 & 7460 & 7945 \\
\hline $\mathbf{T}_{5}$ & $\mathrm{~T}_{2}+40 \mathrm{~kg} \mathrm{MgSO}_{4}$ & 7366 & 8619 & 7010 & 7750 & 7288 & 8245 \\
\hline$T_{6}$ & $\mathrm{~T}_{1}+$ Lime $100 \% \mathrm{EA}$ & 6647 & 7977 & 6495 & 8050 & 6593 & 7615 \\
\hline $\mathbf{T}_{7}$ & $\mathrm{~T}_{6}+20 \mathrm{~kg} \mathrm{MgSO}_{4}$ & 6776 & 7793 & 6530 & 7593 & 7003 & 7660 \\
\hline $\mathbf{T}_{8}$ & $\mathrm{~T}_{6}+30 \mathrm{~kg} \mathrm{MgSO}_{4}$ & 7217 & 8588 & 6780 & 7840 & 6925 & 7580 \\
\hline $\mathbf{T}_{9}$ & $\mathrm{~T}_{6}+40 \mathrm{~kg} \mathrm{MgSO}_{4}$ & 7184 & 8406 & 6620 & 7565 & 7049 & 7447 \\
\hline & SEM \pm & 95.173 & 110.16 & 136.44 & 284.17 & 88.21 & 202.96 \\
\hline & CV & 2.915 & 2.939 & 4.236 & 7.952 & 2.704 & 5.590 \\
\hline & $\mathrm{CD}(5 \%)$ & 291.23 & 340.4 & 407.551 & 865.53 & 266.74 & 617.21 \\
\hline
\end{tabular}

It is quite evident from the result that secondary nutrient management showed improved results. Significant higher exchangeable magnesium was obtained in treatment $\mathrm{T} 5$ (0.525 C.mol $\left(\mathrm{P}^{+}\right) \mathrm{kg}^{-1}$ soil): which received $\mathrm{POP}+$ Lime application equivalent to $50 \%$ exchangeable acidity and $40 \mathrm{~kg}$ Magnesium sulphate and treatment T9 (0.511 C.mol $\left(\mathrm{P}^{+}\right) \mathrm{kg}^{-1}$ soil): which received POP+Lime application equivalent to $100 \%$ exchangeable acidity and $40 \mathrm{~kg}$ Magnesium sulphate followed by treatment T8 $(0.500$ C.mol $\left(\mathrm{P}^{+}\right) \quad \mathrm{kg}^{-1} \quad$ soil): which received POP+Lime application equivalent to $100 \%$ exchangeable acidity and $30 \mathrm{~kg}$ Magnesium sulphate and other treatments showed nonsignificant difference among them. Similar observations were resulted by Vadivel et al., (2001) Subrahmanian et al., (2000) and Rawat and Pareek (2003).
Results pertaining to the effect of soil acidity and secondary nutrient management on grain and straw yield are presented in Table 2. After three years of experiment, the data obtained on grain and straw yield is pooled and analyzed statistically.

Result shows that the application of lime and secondary nutrients along with recommended dose of nutrients had very good impact to improve the soil available nutrients that resulted in higher grain yield in case of treatment $\mathrm{T}_{4}\left(7460 \mathrm{~kg} \mathrm{ha}{ }^{-1}\right): \mathrm{T}_{2}+30 \mathrm{~kg}$ magnesium sulphate followed by the treatment $\mathrm{T}_{5}\left(7288 \mathrm{~kg} \mathrm{ha}^{-1}\right): \mathrm{T}_{2}+40 \mathrm{~kg}$ magnesium sulphate, $\mathrm{T}_{9}\left(7049 \mathrm{~kg} \mathrm{ha}^{-1}\right): \mathrm{T}_{6}+$ $40 \mathrm{~kg}$ magnesium sulphate but other treatments showed non-significant difference among the them. 
A significantly higher straw yield was obtained in case of treatment $\mathrm{T}_{5}(8245 \mathrm{~kg}$ ha $\left.{ }^{1}\right): \mathrm{T}_{2}+40 \mathrm{~kg}$ magnesium sulphate followed by treatment $\mathrm{T}_{4}\left(7945 \mathrm{~kg} \mathrm{ha}^{-1}\right): \mathrm{T}_{2}+30 \mathrm{~kg}$ magnesium sulphate and treatment $\mathrm{T}_{3}(7773$ $\left.\mathrm{kg} \mathrm{ha}{ }^{-1}\right): \mathrm{T}_{2}+20 \mathrm{~kg}$ magnesium sulphate. Similar observations were resulted by Taiwo Agbede and Lawrence Afolabi, 2014, and Rawat and Pareek (2003).

From three years of investigation reveals that lime application equivalent to $50 \%$ exchangeable acidity along with $30 \mathrm{~kg}$ magnesium sulphate recorded significantly higher exchangeable magnesium content and also improved soil available nutrients over other treatments. Which in turn influenced higher nutrient uptake by the crop, thus make favourable influence of lime applied along with magnesium sulphate. Magnesium content in plant may be played its catalytic or stimulatory effect on physiological and metabolic activities of plants which ultimately influenced the significant increase in grain and straw yield.

\section{References}

Rawat, S.S and Pareek, R.G., 2003. Effect of FYM and NPK on yield and nutrient uptake for soil fertility in wheat. Annals of Ari-Bio-Research. 8(1): 17-19.

Rockstrom, J., Hatibu, N., Oweis, T. Y., Wani, S. P., Barron, J., Bruggeman, A., Qiang, Z. 2007. Managing water in rainfed agriculture. In D. Molden (Ed.), Water for food, water for life: A comprehensive assessment of water management in agriculture (pp. 315348). London: Earthscan and Colombo: International Water Management Institute, Sri Lanka.

Sannappa, B. and Manjunath, K.G. 2013. Fertility status of soils in the selected regions of the Western Ghats of
Karnataka, India. Sch. Acad. J. Biosci., 1(5): 200-208.

Singh, A. C. and Singh, S. P., 2001, Growth and yield of spring sunflower and groundnut as influenced by different cropping systems and rates of nitrogen. Ann. Plant Soil Res., 3 (2): 222-225.

Subrahmanian, K. P., Kalaiselvan, and Arulmozhi, N. 2000, Studies on the effect of nutrient spray and graded level of NPK fertilizers on the growth and yield of groundnut. Internl. J. Trop. Agric., 18 (3): 287-290.

Taiwo M. Agbede and Lawrence a. Afolabi, 2014. Soil fertility improvement potentials of Mexican sunflower (Tithonia diversifolia) and Siam weed (Chromolaena odorata) using okra as test crop. Archives of Applied Science Research. 6 (2): 42-47.

Wani, S. P., Sarvesh, K. V., Krishnappa, K., Dharmarajan, B. K., \& Deepaja, S. M. (Eds.) (2012b). Bhoochetana: Mission to boost productivity of rainfed agriculture through science-led interventions in Karnataka. Patancheru: International Crops Research Institute for the Semi-Arid Tropics.

Wani, S. P., Sreedevi, T. K., Rockstro“m, J., \& Ramakrishna, Y. S. 2009. Rainfed agriculture - Past trends and future prospects. In S. P. Wani, J. Rockstro “m, \& T. Oweis (Eds.), Rainfed agriculture: Unlocking the potential (pp. 1-35). Wallingford: CAB International, Comprehensive Assessment of Water Management in Agriculture Series.

Vadivel, N., Subbian, P. and Velayutham, A., 2001. Effect of integrated nutrient management practices on the growth and yield of rainfed winter maize (Zea mays). Indian Journal of Agronomy, 46(2): 250-254. 


\section{How to cite this article:}

Jayaprakash. S. M., S. U. Patil, T. H. Ranjith, R. Jayaprakash and Sudhir Kamath. K. V. 2020. Influence of lime and secondary nutrients on available nutrients and yield of paddy. Int.J.Curr.Microbiol.App.Sci. 9(02): 2228-2233. doi: https://doi.org/10.20546/ijcmas.2020.902.251 